\title{
The relationship between maternal blood group and preeclampsia
}

\author{
Manjunatha S. ${ }^{1 *}$, Anita K. ${ }^{2}$ \\ ${ }^{1}$ Department of Obstetrics and Gynecology, Kodagu Institute of Medical Sciences, Madikeri, Karnataka, India \\ ${ }^{2}$ Department of Physiology, Navodaya Medical College, Raichur, India
}

Received: 02 October 2015

Accepted: 19 October 2015

\section{*Correspondence:}

Dr. Manjunatha S,

E-mail: hsogmanju@gmail.com

Copyright: $\odot$ the author(s), publisher and licensee Medip Academy. This is an open-access article distributed under the terms of the Creative Commons Attribution Non-Commercial License, which permits unrestricted non-commercial use, distribution, and reproduction in any medium, provided the original work is properly cited.

\section{ABSTRACT}

Background: Pre-eclampsia is a pregnancy specific, multisystem, hypertensive disorder characterized by new onset hypertension and proteinuria after 20 weeks of gestation and remission of signs after delivery, which is the leading cause of maternal, fetal and neonatal mortality and morbidity. Despite extensive research, the etiology and pathogenesis of Pre-eclampsia remain obscure and poorly understood. ABO blood groups are known to be associated with many disorders. In this study we have tried to know the relationship between maternal blood group and preeclampsia.

Methods: It is a cross-sectional study. 100 pregnant women with preeclampsia and 100 women with normal pregnancy were selected. Rh negative females or women with any other medical and surgical complication were excluded from the study. Using blood group $\mathrm{O}$ as the reference group, the relation between maternal blood group and preeclampsia was estimated using odds ratios and $95 \%$ confidence intervals from logistic regression models.

Results: When compared with blood group O, women of blood group AB have an increased risk of preeclampsia.

Conclusions: The present study indicates that $\mathrm{AB}$ blood group have the highest risk of developing preeclampsia. $\mathrm{AB}$ blood group is associated with an increased risk of thrombotic events this may be the cause of increased incidence of $\mathrm{PIH}$ in this group. Thus attention should be given to the AB blood group pregnant women in order to prevent the PIH.

Keywords: ABO blood groups, PIH, Pregnant women, Preeclampsia

\section{INTRODUCTION}

Women die as a result of complications during and following pregnancy and childbirth. Most of these complications develop during pregnancy. The major complications that account for nearly $75 \%$ of all maternal deaths are severe bleeding (mostly bleeding after childbirth), infections (usually after childbirth), high blood pressure during pregnancy, complications from delivery unsafe abortion. ${ }^{1}$ In India, roughly one maternal death occurs every five minutes. ${ }^{2}$ Hypertensive disorders complicating pregnancy are common and form one of the deadly triad ,along with haemorrhage and infection, that results in much of the maternal morbidity and mortality related to pregnancy. How pregnancy incites or aggravates hypertension remains unsolved despite decades of intensive research, and hypertensive disorders remain among the most significant unsolved problems in obstetrics. ${ }^{3}$ Preeclampsia is a multisystem disorder of unknown etiology characterised by development of hypertension to the extent of $140 / 90 \mathrm{~mm} \mathrm{Hg}$ or more with protinuria after the 20th week in previously normotensive and non-proteinuric patients. ${ }^{4}$ Pre-eclampsia is a complex pathophysiological state where regulatory systems of inflammation and endothelial function are stimulated beyond the physiological limits of normal pregnancy. ${ }^{5}$ Though there is genetic susceptibility, the pathogenesis of pre-eclampsia has been enigmatic. ${ }^{6,7}$ There is increased association of preeclampsia with the following: primigravida, rhesus incompatibility, diabetes, genetic disorders, pre-existing vascular and renal diseases, $t$ hrombophilias raised body mass index before pregnancy 
etc. ${ }^{5}$ The antigens of ABO blood-group areoligosaccharides that are attached to the cell-surface glycoconjugates and are expressed by epithelia, endothelia and erythrocytes (RBCs) in primates. Susceptibility to diseases such as infections, cancer, cardiovascular diseases and hematologic disorders are found to be been associated with ABO blood groups. It is a key determinant of coagulation factor VIII and von Willebrand factor plasma concentrations. ${ }^{8} \mathrm{ABO}$ antigens may alter the presentation of cell-surface glycans and modulate their interactions with pathogens or may provide receptors for pathogen attachment, hence ABO antigen is associated with various diseases. ABO antigens may play a major role in the interaction of the immune and coagulation systems by influencing geneenvironment interactions. As the current view on preeclampsia suggests that it has an exaggerated maternal systemic immune response component and characteristic changes in coagulation systems, differences in $\mathrm{ABO}$ blood groups may increase the risk of disease according to the inherited antigens.

\section{METHODS}

This cross sectional study was conducted at Navodaya medical college. Institutional ethical clearance was taken. An informed consent was taken from every patient after full explanation of procedure. The subjects for the study were selected from the out-patient and in -patient department of obstetrics and gynaecology and also from the labour room. 100 pregnant women who were fulfilling the criteria for preeclampsia were considered as cases and 100 women with normal pregnancy without any complications were selected as controls. Only Rh positive primi cases were included in the study. Subjects having any other medical and surgical complication and women having history of any drug use, multi-fetal pregnancy, $\mathrm{Rh}$ negative blood group subject smoking, erythroblastosis fetalis, were excluded from the study. Relevant past and personal history from the subjects are taken. General physical examination, vital signs were recorded. A drop of blood was taken from their finger tip using lancet, under aseptic precaution. 1 drop of blood was mixed with $1 \mathrm{ml}$ of normal saline in a test tube. This provided the red cell suspension. Blood group was determined by haemagglutination technique. A drop of monoclonal Anti A, Anti B, Anti D was added separately on a clean glass slide and to each of this a drop of red cell suspension was added. With separate applicator, the serum was well mixed back and forth and observed for agglutination and it was confirmed under low power objective. Results of agglutination were recorded immediately for ABO blood group and after 2 minutes for $\mathrm{Rh}$. The protenuria was measured by urine dipsticks.

\section{Statistical Analysis}

The data were analyzed by using Microsoft Excel and Epinfo. The relationship of blood group with preeclampsia was estimated by calculating odds ratio from logistic regression models using blood group $\mathrm{O}$ and controls respectively as reference group after adjustment for various covariates. A p-value of $<0.05$ was considered as statistically significant.

\section{RESULTS}

The study population consist of 100 cases and 100 controls. Using blood group $\mathrm{O}$ as the reference group, the association between blood group and preeclampsia was estimated using odds ratios and $95 \%$ confidence intervals from logistic regression models. The results as shown in table- 2 indicated that $\mathrm{AB}$ has the highest, and $\mathrm{O}$ has lowest risk for $\mathrm{PIH}$ among the $\mathrm{ABO}$ blood groups.

\section{Table 1: Showing the distribution of different blood groups in both categories.}

\begin{tabular}{|llllll|}
\hline Category & \multicolumn{3}{l}{ Blood group $(\%)$} & & \\
& $\mathrm{A}$ & $\mathrm{B}$ & $\mathrm{AB}$ & $\mathrm{O}$ & Total \\
\hline Cases & 10 & 12 & 50 & 28 & 100 \\
& $(10)$ & $(12)$ & $(50)$ & $(28)$ & \\
\hline Control & 16 & 24 & 6 & 54 & 100 \\
& $(16)$ & $(24)$ & $(6)$ & $(54)$ & \\
\hline
\end{tabular}

Table 2: Showing the association between ABO blood group and PIH.

\begin{tabular}{|llllll|}
$\begin{array}{l}\text { Blood } \\
\text { groups }\end{array}$ & $\begin{array}{l}\text { Odds } \\
\text { ratio }\end{array}$ & $\begin{array}{l}95 \% \\
\text { limit }\end{array}$ & $\begin{array}{l}\text { Lower } \\
\text { bound }\end{array}$ & $\begin{array}{l}\text { Upper } \\
\text { bound }\end{array}$ & $\begin{array}{l}\text { Significance } \\
\text { (P value) }\end{array}$ \\
A & 1.205 & 0.48 & 3.99 & 0.87 & NS \\
\hline B & 0.964 & 0.42 & 2.21 & 0.931 & NS \\
\hline AB & 16.07 & 6.14 & 42.07 & $<0.0001$ & HS \\
\hline
\end{tabular}

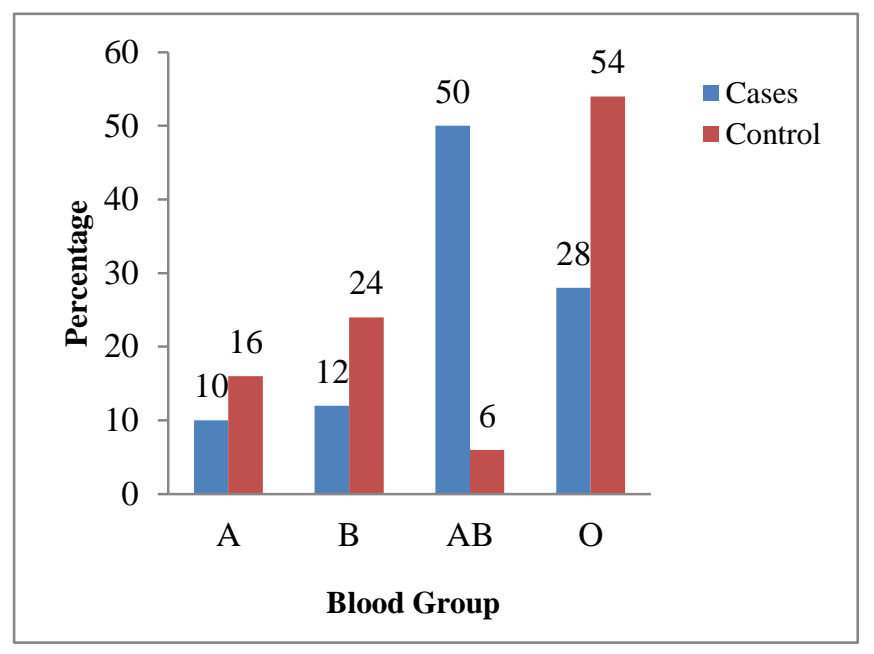

Figure 1: Distribution of different blood groups in both categories.

The reference category is: blood group $\mathrm{O}$ 


\section{DISCUSSION}

The results of our study indicate that women with blood group $\mathrm{AB}$ have the highest risk for preeclampsia compared to other blood group. Preeclampsia, a syndrome unique to human pregnancy and one of the leading causes of maternal and foetal morbidity and mortality, is also associated with maternal blood group. Patients with blood group $\mathrm{AB}$ have an increased risk of severe, early-onset, or intrauterine growth restriction (IUGR) associated forms of preeclampsia. ${ }^{8}$ The results of our study are consistent with findings of Lee $\mathrm{BK}$ et $\mathrm{al}^{9}$ Bharali et al ${ }^{10}$ Spinillo et al ${ }^{11} \mathrm{C}$ Phaloprakram et al. ${ }^{12}$ One suggested mechanism of how blood group influences the risk of gestational hypertensive disorders is through the maternal immune response. Placental Protein ${ }^{13}$ (PP13) is considered to be an early marker for preeclampsia. PP13 is primarily produced by the placenta in anthropoid primates It is a galectin (galectin-13) that binds betagalactosides, such as $\mathrm{N}$-acetyl-galactosamine, galactose, fucose, located at terminal positions on ABO blood-group antigens, with strongest affinity to blood group $\mathrm{AB}{ }^{8}$ In women from $\mathrm{AB}$ group, the close proximity of $\mathrm{A}$ and $\mathrm{B}$ antigens could explain the stronger binding of PP13 to blood group $\mathrm{AB}$ erythrocytes, leading to its sequestration. In consequence the PP13 plasma levels are low in pregnant on the first trimester of gestation, which could predispose pregnancy complications, including preeclampsia. ${ }^{13}$ Compared with $\mathrm{O}$ group, $\mathrm{A}, \mathrm{B}$, and $\mathrm{AB}$ groups are associated with an increased risk of thrombotic events, although this relationship is debated. ABO blood groups may differ in the occurrence of known vascular risk factors for preeclampsia, such as endothelial dysfunction ${ }^{14}$, insulin resistance, ${ }^{15}$ and hypercholesterolemia. ${ }^{16}$ ABO blood group is a key determinant of coagulation factor VIII and von Willebrand factor plasma concentrations. Low plasma concentrations of these glycoproteins in blood-group $\mathrm{O}$ individuals may lead to excess bleeding, while elevated plasma concentrations of these factors in non-O bloodgroup individuals have been implicated in increasing the risk of thromboembolic and ischemic heart diseases. ${ }^{8}$ Recent genome-wide association studies indicate that genetic variants at the $\mathrm{ABO}$ locus are associated with soluble E-selectin, ${ }^{17,18}$ P-selectin, and ICAM-1, ${ }^{19}$ vascular inflammatory agents that are associated with hypertension and type- 2 diabetes. ${ }^{20}$ However, of a diverse panel of inflammatorybiomarkers, including Eselectin, P-selectin, and ICAM-1, a recentstudy found that only E-selectin levels were higher in preeclampsiacases versus controls. $^{21}$

\section{CONCLUSIONS}

The results of this study suggest relationship between ABO blood group systems and PIH preeclampsia with $\mathrm{AB}$ blood group women having highest risk.. Considering the role of $\mathrm{ABO}$ blood groups on the hemostatic process and thrombus formation, special attention should be given to pregnant patients carrying the $\mathrm{AB}$ blood group in order to prevent the preeclampsia and improve prognosis.

Funding: No funding sources

Conflict of interest: None declared

Ethical approval: The study was approved by the Institutional Ethics Committee

\section{REFERENCES}

1. World Health Organization Fact Sheet.2012.

2. Roopa Bakshi, UNICEF unveils new tool to combat maternal mortality in India. UN I CE F.2006.

3. Williams OBSTETRICS, Hypertensive disorders of pregnancy. Mc Graw-Hill; 2001:568.

4. Text book of Obstetrics, D.C.Dutta 2004 D.C. Dutta, Text book of Obstetrics, Hypertensive disorders in pregnancy. New Central Book Agency 2004:222.

5. Wang A, Rana S, Ananth Karumanchi S. Preeclampsia: The Role of Angiogenic Factors in Its Pathogenesis. Physiology. 2009:24:147-58.

6. Eduard Gratacos. Lipid mediated endothelial dysfunction: a common factor to preeclampsia and chronic vascular disease. European journal of obstetrics \& gynecology and Reproductive biology. 2000:92:63-6.

7. Pipkin B, Rubin PC. Pre-eclampsia-the disease of theories. British Medical Bulletin. 1994:50(2):38196.

8. Than NG, Romero R, Meiri H, Erez O, Xu Y, Tarquini $\mathrm{F}$ et al. PP13, Maternal ABO blood groups and the risk assessment of pregnancycomplications. PLoS ONE. 2011;6(7):e21564.

9. Lee BK, Zhang Z, Wikman A, Lindqvist et al. ABO and $\mathrm{RhD}$ blood groups and gestational hypertensive disorders: a population-based cohort study. BJOG. 2012;119(10):1232-7.

10. Bharali R et al. ABO blood group - a risk factor for pregnancy induced hypertension. Int J Biol Med Res. 2014;5(1):3797-801.

11. Spinillo A, capuzzo E, Baltaro F, Piazzi G et al. Case-control study of maternal blood group. J Hum Hypertens. 1995;9(8):623.

12. Phaloprakarn $\mathrm{C}$, Tangjitgamol S. Maternal ABO blood group and adverse pregnancy outcomes Journal of Perinatology. 2013;33:107-11.

13. Alpoim PN, Pinheiro MDB, Junqueira DRG, Freitas LGA et al Preeclampsia and ABO blood groups: a systematic review and meta-analysis. Mol Biol Rep. 2013;40:2253-61.

14. Huppertz B, Sammar M, Chefetz I, NeumaierWagner P, Bartz C, et al. Longitudinal determination of serum placental protein 13 during development of preeclampsia. Fetal Diagn Ther. 2008;24:230-6.

15. Gonen R, Shahar R, Grimpel YI, Chefetz I, Sammar $\mathbf{M}$, et al. Placental protein 13 as an early marker for pre-eclampsia: a prospective longitudinal study. BJOG. 2008;115:1465-72. 
16. Khalil A, Cowans NJ, Spencer K, Goichman S, Meiri H, et al. (2009) First trimester maternal serum placental protein 13 for the prediction of preeclampsia in women with a priori high risk. Prenat Diagn. 2009;29:781-9.

17. Thadhani R, Stampfer MJ, Hunter DJ, Manson JE, Solomon CG, Curhan GC. High body mass index and hypercholesterolemia: risk of hypertensive disorders of pregnancy. Obstet Gynecol. 1999;94:543-50.

18. Paterson AD, Lopes-Virella MF, Waggott D, Boright AP, Hosseini SM, Carter RE, et al. Genome-wide association identifies the ABO blood group as a major locus associated with serum levels of soluble E-selectin. ArteriosclerThromb Vasc Biol. 2009;29:1958-67.

19. Barbalic M, Dupuis J, Dehghan A, Bis JC, Hoogeveen RC, Schnabel RB, et al.Large-scale genomic studies reveal central role of $\mathrm{ABO}$ in $\mathrm{sP}$ selectin and sICAM-1 levels. Hum Mol Genet. 2010;19:18

20. Meigs JB, Hu FB, Rifai N, Manson JE. Biomarkers of endothelial dysfunction and risk of type 2 diabetes mellitus. JAMA. 2004;291:1978-86.

21. Carty DM, Anderson LA, Freeman DJ, Welsh PI, Brennand JE, Dominiczak AF,et al. Early pregnancy soluble E-selectin concentrations and risk of preeclampsia. J Hypertens. 2012;30:954-9.

Cite this article as: Manjunatha S, Anita K. The relationship between maternal blood group and preeclampsia. Int J Reprod Contracept Obstet Gynecol 2015;4:1749-52. 